\title{
Airborne observations of IEPOX-derived isoprene SOA in the Amazon during SAMBBA
}

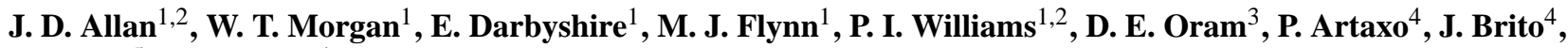 \\ J. D. Lee ${ }^{5}$, and H. Coe ${ }^{1}$ \\ ${ }^{1}$ School of Earth, Atmospheric and Environmental Sciences, University of Manchester, UK \\ ${ }^{2}$ National Centre for Atmospheric Science, University of Manchester, UK \\ ${ }^{3}$ Centre for Ocean and Atmospheric Sciences \& National Centre for Atmospheric Science, \\ School of Environmental Sciences, University of East Anglia, Norwich, UK \\ ${ }^{4}$ Physics Institute, University of São Paulo, Brazil \\ ${ }^{5}$ National Centre for Atmospheric Science \& Wolfson Atmospheric Chemistry Laboratory, \\ University of York, UK \\ Correspondence to: J. D. Allan (james.allan@ manchester.ac.uk)
}

Received: 17 April 2014 - Published in Atmos. Chem. Phys. Discuss.: 19 May 2014

Revised: 9 September 2014 - Accepted: 20 September 2014 - Published: 29 October 2014

\begin{abstract}
Isoprene is a potentially highly significant but currently poorly quantified source of secondary organic aerosols (SOA). This is especially important in the tropics, where large rainforests act as significant sources of isoprene. Methylfuran, produced through thermal decomposition during analysis, has recently been suggested as a marker for isoprene SOA formation through the isoprene epoxydiol (IEPOX) route, which mostly occurs under low $\mathrm{NO}_{\mathrm{x}}$ conditions. This is manifested as a peak at $m / z=82$ in Aerodyne Aerosol Mass Spectrometer (AMS) data. Here we present a study of this marker measured during five flights over the Amazon rainforest on board the UK Facility for Airborne Atmospheric Measurement (FAAM) BAe-146 research aircraft during the South American Biomass Burning Analysis (SAMBBA) campaign. Cases where this marker is and is not present are contrasted and linked to the presence of acidic seed particles, lower $\mathrm{NO}_{\mathrm{x}}$ concentrations and higher humidities. There are also data to suggest a role of organic nitrogen in the particulate composition. Furthermore, an inspection of the vertical trends of the marker indicates that concentrations are highest at the top of the boundary layer (possibly due to semivolatile repartitioning) and that upwards through the free troposphere, the mass spectral profile evolves towards that of low volatility oxygenated aerosol. These observations offer insights into the behaviour of IEPOX-derived SOA formation above the Amazon rainforest and the suitability of methylfuran as a marker for this process.
\end{abstract}

\section{Introduction}

The processes controlling secondary organic aerosols (SOA) remain a continuing source of uncertainty in our predictive capability of atmospheric composition (Hallquist et al., 2009). These are formed from both natural and anthropogenic precursors and are subject to many complex and often poorly understood processes that control the formation. Of specific interest in recent years is the formation of SOA from isoprene (Claeys et al., 2004; Carlton et al., 2009; Claeys et al., 2010). Because of isoprene's abundance in the atmosphere, this could represent a significant portion of the SOA budget in certain regions, even if its mass yield is low relative to other natural VOCs such as monoterpenes and sesquiterpenes. While evidence for isoprene SOA formation has existed for some time, laboratory studies have shown that yields are highly variable and dependent on parameters such as $\mathrm{NO}_{\mathrm{x}}$ concentrations and the composition of the seed particles (Czoschke et al., 2003). One particular mechanism that has received much attention is through the formation of isoprene expoxydiols (IEPOX) under low- $\mathrm{NO}_{\mathrm{x}}$ conditions and reactive uptake to the particle phase, which produces markers that have been observed in the atmosphere such as 2methyltetrols (Paulot et al., 2009; Chan et al., 2010; Surratt et al., 2010; Surratt et al., 2006; Kroll et al., 2006). The work of Pye et al. (2013) indicates that model representation of these processes can produce the marker compounds in quantities comparable to observations. 
Another proposed marker is methylfuran, which has been detected using the Aerodyne Aerosol Mass Spectrometer (AMS) and two-dimensional gas-chromatography massspectrometry analysis of filter samples, first identified by Robinson et al. (2011) in Borneo as part of the Oxidant and Particle Photochemical Processes above a Southeast Asian tropical rain forest (OP3) campaign (Hewitt et al., 2010). This is not in itself present in the particles (being too volatile), but is thought to be produced through the decomposition of IEPOX SOA species such as 3methyltetrahydrofuran-3,4-diols (3-MeTHF-3,4-diols) during the thermal desorption used in both techniques (Lin et al., 2012). Methylfuran is a particularly useful marker because it produces a distinctive signal in the AMS mass spectrum at $m / z=82$. While the majority of the mass is contained within other peaks, these are common to many other forms of SOA and are therefore unsuitable for marker-based analysis. Normally, this peak constitutes no more than $4 \%$ of the organic signal, so a higher fraction can be seen as evidence of the marker being present. While the majority of the mass is contained within other peaks (Robinson et al., 2011; KiendlerScharr et al., 2012), these are common to many other forms of SOA and are therefore unsuitable for marker-based analysis. Furthermore, this marker can also form the basis of a factor obtained using Positive Matrix Factorisation (PMF) (U1brich et al., 2009), which allows the total amount of organic matter covariant with this marker to be quantified. This can then be used as an estimate of isoprene SOA formed under these conditions, not just that which gives rise to the methylfuran marker. This will also apply to the analysis of data from the Aerosol Chemical Speciation Monitor (ACSM), an instrument similar in function to the AMS but more optimised for long-term monitoring ( $\mathrm{Ng}$ et al., 2011).

This marker has now been reported in a number of environments using ground-based AMS and ACSM measurements, for example in Canada (Slowik et al., 2011) and downtown Atlanta, GA (Budisulistiorini et al., 2013), consistent with the formation of isoprene SOA through the IEPOX route, although not enough data currently exist to form a universal picture of its behaviour. Tropical environments are of particular interest because of the dominance of isoprene in the biogenic VOC budgets (Guenther et al., 2006) and the often lower anthropogenic influence, resulting in lower $\mathrm{NO}_{\mathrm{x}}$ concentrations. To date, the $\mathrm{m} / \mathrm{z}=82$ marker has been reported from ground- and aircraft-based measurements in Borneo and ground-based measurements in the Amazon (Chen et al., 2009, 2014). Here we present, for the first time, airborne measurements of this marker above the Amazon. The measurements were performed as part of the South AMerican Biomass Burning Analysis (SAMBBA) campaign in 2012, using the Facility for Airborne Atmospheric Measurements (FAAM) BAe-146 research aircraft, with a similar instrument payload as used in Robinson et al. (2011). (a)

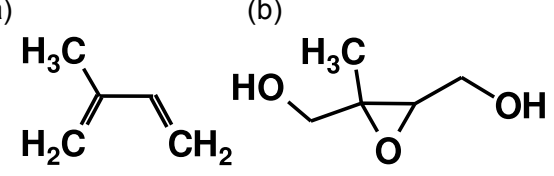

(c)

(d)

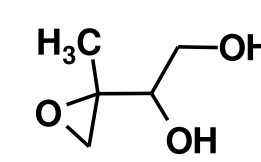

(e)

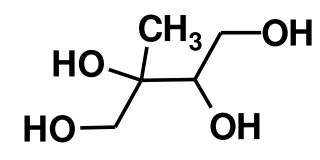

(f)

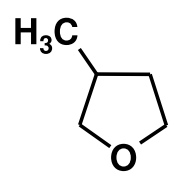

Figure 1. Organic species referred to in this paper: (a) Isoprene, (b) $\beta$-IEPOX, (c) $\delta$-IEPOX, (d) 2-methyltetrol, (e) 3 methyltetrahydrofuran-3,4-diol and (f) 3-methylfuran.

\section{Experiment}

\subsection{Flight details}

While the primary focus of the SAMBBA campaign was the study of biomass burning, a number of flights were conducted over areas of unperturbed rainforest to study biogenic processes. The flights occurred after the onset of the transition to the wet season, where the weather within Brazil became more unsettled. Due to wet deposition and a change in synoptic transport, this resulted in generally lower concentrations of anthropogenic emissions compared to the later stages of the dry season, when biomass burning was at its peak.

In total, five biogenic flights took place, which are summarised in Fig. 2 and Table 1. The first flight, B735, partly collected high-altitude data between Porto Velho and Manaus. However, periods of flying over the rainforest also took place. The remaining four flights took place out of Porto Velho and followed a similar format to that used during OP3, where one flight took place around midday (local time), with a second flight in the afternoon after refuelling. This was designed such that the chemistry could be contrasted, with the expectation that the midday flight would occur when the biogenic VOCs would be at their peak and the afternoon flight when the oxidation products would be more significant. B744 and B745 took place over the Pacaás Novos national park to the south of Porto Velho in Rondônia and B749 and B750 flew over the rainforest in Amazonas to the north of Porto Velho. 
Table 1. Composition statistics for the data taken below $2 \mathrm{~km}$ for the five flights, with standard deviations, shown to 3 significant digits. Time periods refer to AMS data coverage. All mass concentrations are reported at standard temperature and pressure $(273.15 \mathrm{~K}, 1013 \mathrm{hPa})$. Quantities denoted by * were impacted by an inlet blockage and failed quantification quality checks.

\begin{tabular}{|c|c|c|c|c|c|}
\hline Flight & B735 & B744 & B745 & B749 & B750 \\
\hline \multirow{2}{*}{$\begin{array}{l}\text { Date and time } \\
\text { (UTC-4) }\end{array}$} & 19 Sep 2012 & 28 Sep 2012 & 28 Sep 2012 & 03 Oct 2012 & 03 Oct 2012 \\
\hline & $07: 59-11: 48$ & $08: 50-12: 44$ & $13: 58-17: 07$ & $09: 33-13: 30$ & $14: 57-17: 35$ \\
\hline \multirow[t]{2}{*}{ Region } & Amazon & Pacaás & Pacaás & Amazon & Amazon \\
\hline & (Manaus) & Novos & Novos & (Porto Velho) & (Porto Velho) \\
\hline $\operatorname{Org}_{\text {Total }}\left(\mu \mathrm{g} \mathrm{m}^{-3}\right)$ & $0.614^{*} \pm 0.275$ & $5.46 \pm 1.94$ & $5.53 \pm 1.74$ & $3.36 \pm 1.16$ & $2.41 \pm 1.03$ \\
\hline $\operatorname{Org}_{82}\left(\mathrm{ng} \mathrm{m}^{-3}\right)$ & $5.49 * \pm 3.29$ & $22.1 \pm 8.0$ & $22.2 \pm 6.4$ & $28.5 \pm 10.2$ & $22.4 \pm 9.3$ \\
\hline $\mathrm{SO}_{4}^{2-}\left(\mathrm{ng} \mathrm{m}^{-3}\right)$ & $137 * \pm 55$ & $484 \pm 163$ & $451 \pm 65$ & $425 \pm 139$ & $327 \pm 104$ \\
\hline $\mathrm{NO}_{3}^{-}\left(\mathrm{ng} \mathrm{m}^{-3}\right)$ & $29.8^{*} \pm 31.6$ & $261 \pm 167$ & $232 \pm 241$ & $137 \pm 69$ & $97.7 \pm 72.7$ \\
\hline $\mathrm{NH}_{4}^{+}\left(\mathrm{ng} \mathrm{m}^{-3}\right)$ & $12.3^{*} \pm 59.4$ & $242 \pm 154$ & $212 \pm 135$ & $110 \pm 96$ & $41.8 \pm 84.7$ \\
\hline $\mathrm{rBC}\left(\mathrm{ng} \mathrm{m}^{-3}\right)$ & $582 \pm 258$ & $434 \pm 144$ & $463 \pm 148$ & $371 \pm 61$ & $259 \pm 67$ \\
\hline Isoprene (ppbv) & $3.58 \pm 2.32$ & $0.62 \pm 1.02$ & $1.44 \pm 1.51$ & $4.77 \pm 1.98$ & $1.81 \pm 1.49$ \\
\hline NO (pptv) & $11.9 \pm 7.8$ & $28.9 \pm 12.0$ & $35.7 \pm 51.1$ & $19.0 \pm 8.9$ & $8.84 \pm 8.07$ \\
\hline $\mathrm{NO}_{2}$ (pptv) & $64.3 \pm 31.1$ & $174 \pm 44$ & $256 \pm 194$ & $47.5 \pm 24.8$ & $119 \pm 37$ \\
\hline
\end{tabular}

Table 2. Diagnostic ratios for the five flights. All ratios are slopes from linear regressions (with intercepts fixed at 0 ) with associated uncertainties, except $\mathrm{Org}_{82} / \mathrm{Org}_{\text {Total }}$, which is a ratio of means with associated standard error, for the sake of comparability with Robinson et al. (2011), although due to the high degree of correlation, slopes from linear regressions were numerically very similar. With $M_{30} / M_{46}$, $M_{46}$ was treated as the dependent variable due to its lower signal-to-noise.

\begin{tabular}{llllll}
\hline Flight & $\mathrm{B} 735$ & $\mathrm{~B} 744$ & $\mathrm{~B} 745$ & $\mathrm{~B} 749$ & $\mathrm{~B} 750$ \\
\hline$r_{\text {Org, } 82}^{2}$ & 0.2129 & 0.867 & 0.856 & 0.795 & 0.831 \\
$\mathrm{Org}_{82} / \mathrm{Org}_{\text {Total }}(\% o)$ & $8.94 \pm 0.23$ & $4.05 \pm 0.03$ & $4.01 \pm 0.02$ & $8.48 \pm 0.07$ & $9.30 \pm 0.08$ \\
$M_{30} / M_{46}$ & $7.74 \pm 1.25$ & $1.83 \pm 0.02$ & $2.27 \pm 0.02$ & $4.07 \pm 0.11$ & $5.75 \pm 0.15$ \\
$\mathrm{NH}_{4}^{+} / \mathrm{NH}_{4}^{+}$Neut & $0.277 \pm 0.040$ & $1.05 \pm 0.019$ & $0.913 \pm 0.015$ & $0.601 \pm 0.016$ & $0.321 \pm 0.022$ \\
$\mathrm{NH}_{4}^{+} / \mathrm{NH}_{4}^{+} \mathrm{SO}_{4}$ & $0.316 \pm 0.048$ & $1.56 \pm 0.03$ & $1.42 \pm 0.03$ & $0.783 \pm 0.022$ & $0.404 \pm 0.029$ \\
$r_{\text {Org,rBC }}^{2}$ & 0.490 & 0.754 & 0.386 & 0.329 & 0.561 \\
\hline
\end{tabular}

\subsection{Instrumentation}

All of the onboard aerosol instruments used Rosemount inlets (Foltescu et al., 1995). While these are known to incur sampling artefacts for larger particles, they are deemed adequate for the submicron particles of interest here (Trembath et al., 2012). Naphion driers were used upstream of the aerosol instruments to prevent condensation of water in the inlet lines (but not to specifically sample the aerosol "dry"), meaning aerosols were typically sampled at an RH of around $50-60 \%$.

An Aerodyne Research (Billerica, MA, USA) AMS was used to make measurements of nonrefractory aerosol composition. This was a Compact Time of Flight (CTOF) type AMS (Canagaratna et al., 2007; Drewnick et al., 2005), as used in OP3 and other previous FAAM publications (Robinson et al., 2011; Morgan et al., 2010b). Detection limits are around $40 \mathrm{ng} \mathrm{m}^{-3}$ for organics and ammonium and $5 \mathrm{ng} \mathrm{m}^{-3}$ for nitrate and sulfate (Drewnick et al., 2009), with an estimated accuracy (neglecting uncertainty in collection efficiency) of around $10 \%$. Calibrations were performed using monodis- perse ammonium nitrate and ammonium sulfate to generate ionisation efficiency data for nitrate and relative ionisation efficiencies for ammonium and sulfate. Equivalent volume concentrations incorporating black carbon data (see below) and using the densities recommended by Cross et al. (2007) were compared against those from a Scanning Mobility Particle Sizer (SMPS) and the comparison was good (85-90\% of SMPS volume) if a collection efficiency (CE) of 1 was used for most flights during the campaign. Certain flights (in particular B749 and B750) had less favourable volume comparisons (around 50\%), however these took place during higher humidity conditions (see below) and given that the SMPS employed no sheath air drying, its data are seen as an unreliable reflection of the "dry" volume measured by the AMS under these conditions, so a CE of 1 is assumed for all flights for the sake of internal consistency. This is inconsistent with the parameterisation of Middlebrook et al. (2012), where a lower CE would be expected (based on the inorganic composition not being dominated by either ammonium nitrate or sulfuric acid and the sampling humidity being less than $80 \%$ ), but is the same as previous observations in the 


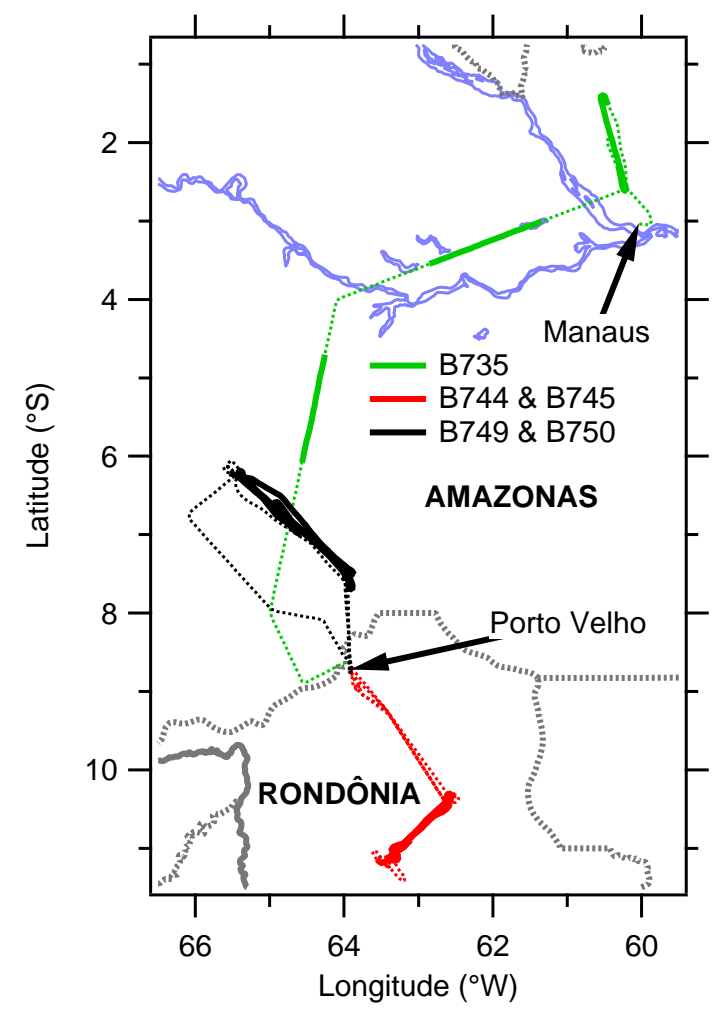

Figure 2. Tracks of the flights presented in this paper. The portions of the flights used in generating the statistics in Tables 1 and 2 (altitude below $2 \mathrm{~km}$, excluding takeoffs, landings and approaches) are shown as solid lines, with the rest of the flights as dotted.

Amazon presented by Chen et al. (2009), who ascribed the higher $\mathrm{CE}$ to the organically dominated particles adopting a liquid phase. An exception to these was B735, where the AMS reported an equivalent volume concentration of around an order of magnitude less than that of the SMPS. At the time, the inlet flow was reduced, indicating a partial blockage of the inlet pinhole. The pinhole was cleaned afterwards and subsequent data had more favourable comparisons with the SMPS and other instruments, implying that the blockage was causing a large fraction of the particles to be lost at the inlet. However, the data are still included here because the data on mass ratios should still be representative of the ambient. This is assuming that the losses apply to all chemical constituents equally; while the losses may be size dependent, the composition is likely to be equal for all sizes if it is dominated by secondary material.

Measurements of black carbon were made using a Droplet Measurement Technologies (Boulder, CO, USA) Single Particle Soot Photometer (SP2). This is the same instrument that was used in previous FAAM publications (McMeeking et al., 2010). It was calibrated using monodisperse AquaDAG (Acheson Industries), with a correction of 0.75 applied according to Laborde et al. (2012a). The instrument measures refractory black carbon, denoted as rBC according to the def- initions recommended by Petzold et al. (2013). Note that the SP2 employs active drying on its sheath air system, so particles are sampled at a low RH. Overall accuracy is estimated at around $20 \%$ with $90 \mathrm{~nm}$ sphere equivalent $\mathrm{rBC}$ volume necessary for particle detection (Laborde et al., 2012b).

Measurements of isoprene were made using an onboard proton transfer reaction mass spectrometer (PTR-MS, Ionicon, Innsbruck, Austria) containing a quadrupole detector. The instrument measured a range of hydrocarbons and oxygenated hydrocarbons with a typical cycle time of around 3$5 \mathrm{~s}$. Isoprene was calibrated against gas standards provided by Apel-Reimer Environmental (Broomfield, CO, USA). The instrument was the same as used during OP3 and full instrumental, operational and calibration details are described in Murphy et al. (2010). Accuracy for isoprene is estimated at $\pm 15 \%$ and data were validated against offline gas chromatography analysis of samples taken using the aircraft's Whole Air Sampling (WAS) system, using the methods described by Hopkins et al. (2011).

Measurements of NO were made using a custom-built chemiluminescence instrument (Air Quality Design Inc, Wheat Ridge, $\mathrm{CO}$, USA), with $\mathrm{NO}_{2}$ measured on a second channel after photolytic conversion to NO. The instrument was the same as used during OP3 (Pike et al., 2010) and the use of photolytic (as opposed to catalytic) conversion eliminates possible interference from $\mathrm{NO}_{\mathrm{z}}$ on the $\mathrm{NO}_{2}$ channel. Detection limits are of the order of $10 \mathrm{pptv}$ for NO and 15 pptv for $\mathrm{NO}_{2}$ for $10 \mathrm{~s}$ averaged data, with estimated accuracies of $15 \%$ for $\mathrm{NO}$ at $0.1 \mathrm{ppbv}$ and $20 \%$ for $\mathrm{NO}_{2}$ at $0.1 \mathrm{ppbv}$.

Navigational data were provided by an Applanix (Richmond Hill, ON, Canada) POS AV 510 GPS-aided inertial navigational unit and altitudes are quoted as above mean sea level. Temperature and pressure were provided by flight instrumentation and humidity was measured (as a dew point accurate to $\pm 0.2^{\circ} \mathrm{C}$ ) using two chilled mirror hygrometers; a General Eastern 1011B (GE Measurement \& Control) and a Buck Research Instruments (Boulder, CO, USA) model CR2. The data presented here are derived from the General Eastern instrument, although the two instruments were in good agreement.

\section{Results}

\subsection{General results}

Because the chemical processes are known to principally take place in the boundary layer, the primary statistics have been calculated for those periods of the flights where the aircraft was below an altitude of $2 \mathrm{~km}$. Takeoffs, landings and approaches were excluded from the analysis to eliminate the influences of the airports and associated cities.

In addition to the total organic matter $\left(\mathrm{Org}_{\text {Total }}\right)$, the organic contribution from $m / z=82$ is also shown $\left(\operatorname{Org}_{82}\right)$, with 
the same relative ionisation efficiency (RIE) applied (1.4). As can be seen, none of the flights were completely free of influence from combustion (assumed anthropogenic) sources, as evidenced by the presence of $\mathrm{rBC}$. The concentrations of anthropogenic emissions were highest in B744 and B745, which also featured the highest organic mass concentrations. This may be due to agricultural activities elsewhere in Rondônia. However, the concentrations in general would still be considered lower than the regional polluted hazes (Darbyshire et al., in preparation for this special issue), so we postulate that pollution levels have been reduced through mixing with cleaner air or wet deposition. Nitrate was also reported in all of the flights, using the standard AMS fragmentation tables (Allan et al., 2004), although as will be shown below, there is reason to suspect that this may not entirely be due to ammonium nitrate. Isoprene was present in all the flights, indicating that strong biogenic emissions and associated chemical processes were taking place.

Further information regarding the composition of the aerosol and possible chemical processes can be obtained by inspecting correlations and ratios between the various measured quantities. These are shown in Table 2. With the exception of B735 (whose data had a low signal-to-noise ratio), the correlations between $\operatorname{Org}_{82}$ and $\operatorname{Org}_{\text {Total }}$ were generally better than those reported by Robinson et al. (2011), which is almost certainly due to the lack of ground-based anthropogenic sources; OP3 was heavily impacted by emissions associated with palm oil agriculture and processing, which provided a large source of variability in organic composition. In contrast, the composition of the organic aerosol was more homogeneous here. The $\mathrm{Org}_{82} / \mathrm{Org}_{\text {Total }}$ ratios for B744 and B745 were consistent with the lower end of the scale presented by Robinson et al. (2011), whereas B735, B749 and B750 were very high in comparison, implying the methylfuran marker was not present in B744 and B745, but present in the others.

Using the default data products, all flights would appear to have significant ammonium nitrate concentrations, which would imply that the aerosol was $\mathrm{pH}$ neutral, as nitrate would partition into the gas phase as nitric acid in the presence of acidic sulfate particles. However, this is at odds with the comparison between the measured ammonium and the calculated amounts of ammonium that would be required to neutralise the sulfate and nitrate measured $\left(\mathrm{NH}_{4}^{+} / \mathrm{NH}_{4}^{+}{ }_{\text {Neut }}\right)$, which implies that B735, B749 and B750 had acidic aerosols. Organic nitrogen species can also contribute to the apparent nitrate signal, a phenomenon that has been reported in other forested environments (Allan et al., 2006). A key diagnostic is the comparison of the signals at $\mathrm{m} / \mathrm{z} 30$ and $46\left(M_{30}\right.$ and $\left.M_{46}\right)$, as organic nitrates and amines will give stronger signals at 30 (as $\mathrm{NO}^{+}$and $\mathrm{CNH}_{4}^{+}$respectively) over $46\left(\mathrm{NO}_{2}^{+}\right)$, compared to ammonium nitrate. As can be seen in Table 2, all flights reported higher values than the ammonium nitrate ratio of 1.54 measured during calibrations, implying that organic nitrogen was present. It should be noted that a signal at 30 can also arise from $\mathrm{CH}_{2} \mathrm{O}^{+}$ions from oxygenated or- ganics. While this generally tends to be a very minor organic fragment under most ambient conditions, the dominance of organics over inorganics in this instance means that it cannot be ruled out. However, this being the case, this would not detract from the argument that it is not as a result of inorganic nitrate.

On the assumption that the nitrate reported was not ammonium nitrate, the ammonium balance calculation was repeated for sulfate in isolation $\left(\mathrm{NH}_{4}^{+} / \mathrm{NH}_{4}^{+} \mathrm{SO}_{4}\right)$. According to this, B735, B749 and B750 were still judged acidic, whereas B744 and B745 apparently had an excess of ammonium. This is again not deemed physically possible, as under alkaline conditions, ammonium partitions into the gas phase as ammonia. This, along with the lower $M_{30} / M_{46}$ value, leads us to conclude that the reported nitrate was mostly ammonium nitrate and the aerosol was neutral for these two flights, although there is still evidence for there being at least some organic nitrogen present. While reassigning a portion of the inorganic nitrate would similarly imply an excess of ammonium, a small charge imbalance could be offset by organic acids, which are not included in the calculation.

Because $\mathrm{rBC}$ was present in all flights, the possibility that biomass burning (or other combustion sources) was responsible for all the organic matter observed must be discounted. The correlation between $\mathrm{rBC}$ and $\mathrm{Org}_{\text {Total }}$ was generally weak but not non-existent. There was not an appreciable signal at $m / z=60$, which is often taken as a marker for biomass burning (e.g. Allan et al., 2010; DeCarlo et al., 2010; Alfarra et al., 2007), although it should be noted that this is known to be diminished in aged plumes (Capes et al., 2008; Cubison et al., 2011). Attempts at using PMF did not resolve any meaningful organic factors that correlated with rBC. While these inferences do not rule out a contribution from combustion, they similarly do not rule out a contribution from isoprene SOA. This issue is discussed further in the following section.

\subsection{Vertical structure}

One of the runs during B749 was performed using a "sawtooth" manoeuvre, with a sequence of three profile ascents and descents designed to probe the structure of the boundary layer and lower troposphere. The results of this are shown in Fig. 3. Figure 3a shows the organic mass concentration was highest at an altitude of approximately $1.5 \mathrm{~km}$. The mass concentrations decreased uniformly with lower and higher altitudes, with the exception of a layer of reduced concentrations at around $2 \mathrm{~km}$ during the final ascent and descent.

Figure $3 \mathrm{~b}$ shows the temperature and humidity data for the profiles. The potential temperature $(\theta)$ is flat up to $1 \mathrm{~km}$, indicating that a well-mixed boundary layer exists up to this altitude. Above $1 \mathrm{~km}$, a positive gradient in $\theta$ but a negative gradient in equivalent potential temperature $\left(\theta_{e}\right)$ is observed, showing that the lower free troposphere is conditionally unstable. A similar structure was noted in Borneo, and 
(a)
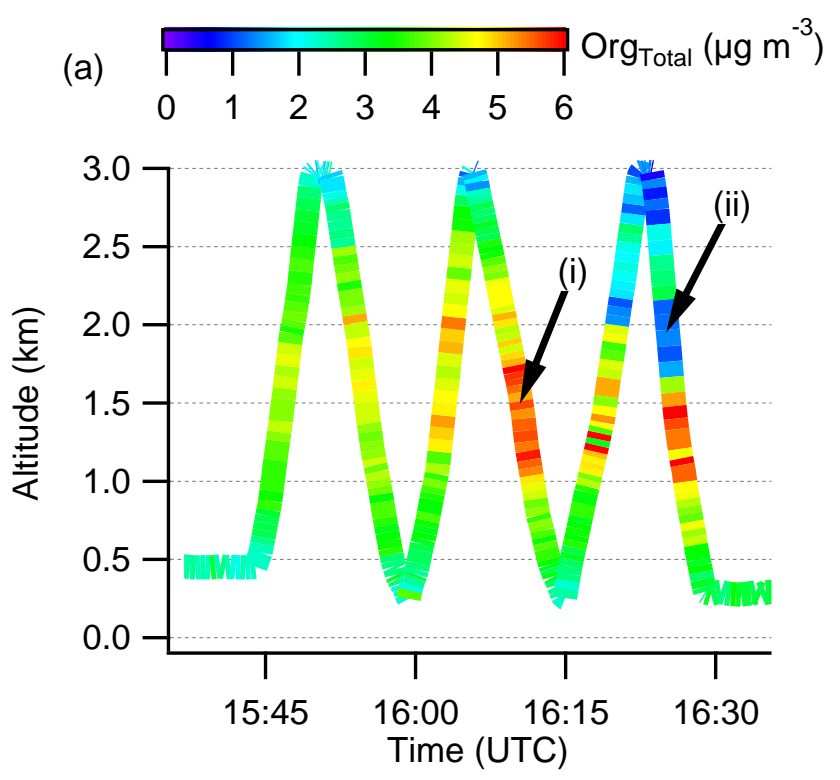

(b)

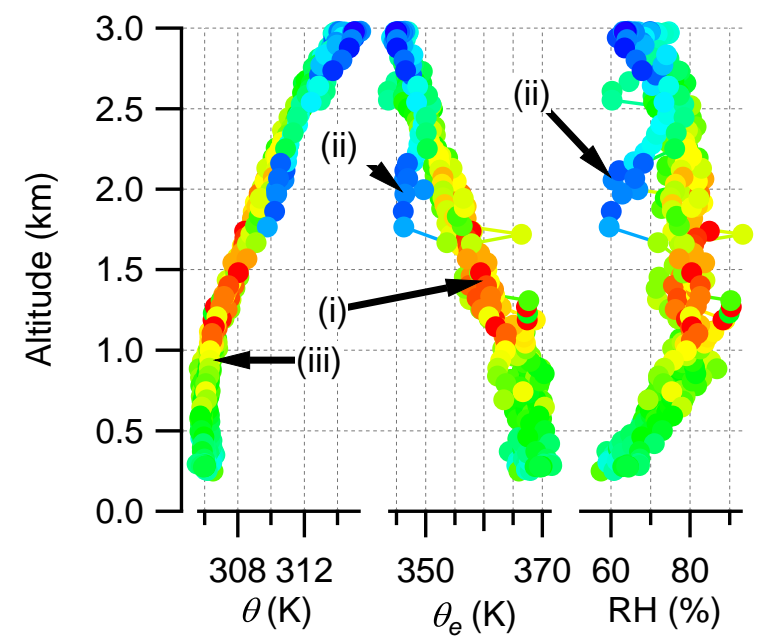

Figure 3. Profile data of potential temperature $(\theta)$, equivalent potential temperature $\left(\theta_{e}\right)$ and relative humidity $(\mathrm{RH})$ from the B749 "sawtooth" manoeuvre, coloured according to organic mass concentration. Highlighted are the (i) peak in organic concentration, (ii) layer of low mass concentration and humidity and (iii) top of the well-mixed boundary layer, as evidenced by $\theta$.

under these conditions, upward transport of material from the boundary layer can occur through nonprecipitating cumulus (Robinson et al., 2012). The low concentrations recorded at $2 \mathrm{~km}$ and discussed above correspond to an anomalously low $\theta_{e}$ and corresponding relative humidity, indicating that this layer of low mass concentrations was a result of clean, dry air being mixed downwards from the free troposphere rather than being transported upwards from the boundary layer.

To investigate the behaviour of the organic and $\mathrm{rBC}$ fractions further, profiles from the various flights are compared in Fig. 4. Flight B735 was omitted because of the relatively small amount of profile data collected over the forest. Similarly, B750 was also excluded because this flight was subject to significant precipitation, which caused a loss of particulate though wet deposition and inconsistent concentrations along the flight tracks. B744 and B745 are compared against B749, as the low $\mathrm{Org}_{82} / \mathrm{Org}_{\text {Total }}$ case versus the contrasting high case.

In both cases, the concentrations decrease with altitude above $1.5 \mathrm{~km}$. In the B744-5 case, the ratios $\operatorname{Org}_{82} / \operatorname{Org}_{\text {Total }}$ and $\mathrm{Org}_{\text {Total }} / \mathrm{rBC}$ show no trend with altitude, suggesting that the aerosol is relatively uniform in composition if not concentration. In contrast, in B749, both metrics show significant vertical structure. The positive gradient in $\mathrm{Org}_{\text {Total }} / \mathrm{rBC}$ is particularly significant, as this indicates that during this flight, the organics do not originate from the same source as the black carbon. If they had a common source, one would expect a uniform profile of $\operatorname{Org}_{\text {Total }} / \mathrm{rBC}$ within the wellmixed boundary layer, as was seen in B744-5 and the polluted regional hazes studied by Darbyshire et al. (in preparation). The organics peak at around $1 \mathrm{~km}$, consistent with the formation of SOA at the top of the boundary layer, superimposed on a background of $\mathrm{rBC}$ (and potentially some organics). The absolute values of $\operatorname{Org}_{\text {Total }} / \mathrm{rBC}$ are not high compared to the values of approximately 10 noted in the polluted regional hazes, but it should be noted that if a polluted air mass had been subjected to wet deposition (which, given the synoptic conditions, is likely to have been the case), non-rBC particles would be preferentially removed, being larger and more soluble and therefore more subject to in-cloud scavenging. As such, this could result in a background $\mathrm{Org}_{\text {Total }} / \mathrm{rBC}$ being lower, which is increased back to around 10 through the formation of SOA.

The fractional contribution from $\mathrm{Org}_{82}$ peaks at around $0.5-1 \mathrm{~km}$ in B749, which shows this marker is most significant at the top of the boundary layer. It decreases with altitude, but it is worth noting that it does not fully decrease to the $4 \%$ value of $\mathrm{B} 744-5$, which is also the general minimum reported by Robinson et al. (2011). Potential reasons for this decrease are covered in the discussion section.

The inorganic profiles are shown in Fig. 5. In both cases, the general loadings show an initial increase in concentration with altitude within the boundary layer, although unlike the organic trend in B749, the concentration of sulfate in particular continues to increase beyond $1 \mathrm{~km}$, up to $1.5 \mathrm{~km}$. If sulfate is compared with $\mathrm{rBC}$ (as a proxy for regional haze), a positive trend is noted that continues to high altitudes, which is consistent with sulfate originating from sources outside of the Amazon Basin and being transported downwards from the free troposphere, as described by Chen et al. (2009). The behaviour of nitrate is interesting, with the $M_{30} / M_{46}$ diagnostic higher within the boundary layer in both cases, which would be consistent with the formation of organic nitrogen. However, when comparing organic mass concentration with $M_{30}$ (as a proxy for organic nitrogen), the two cases show very different behaviour, with the ratio for B749 being 


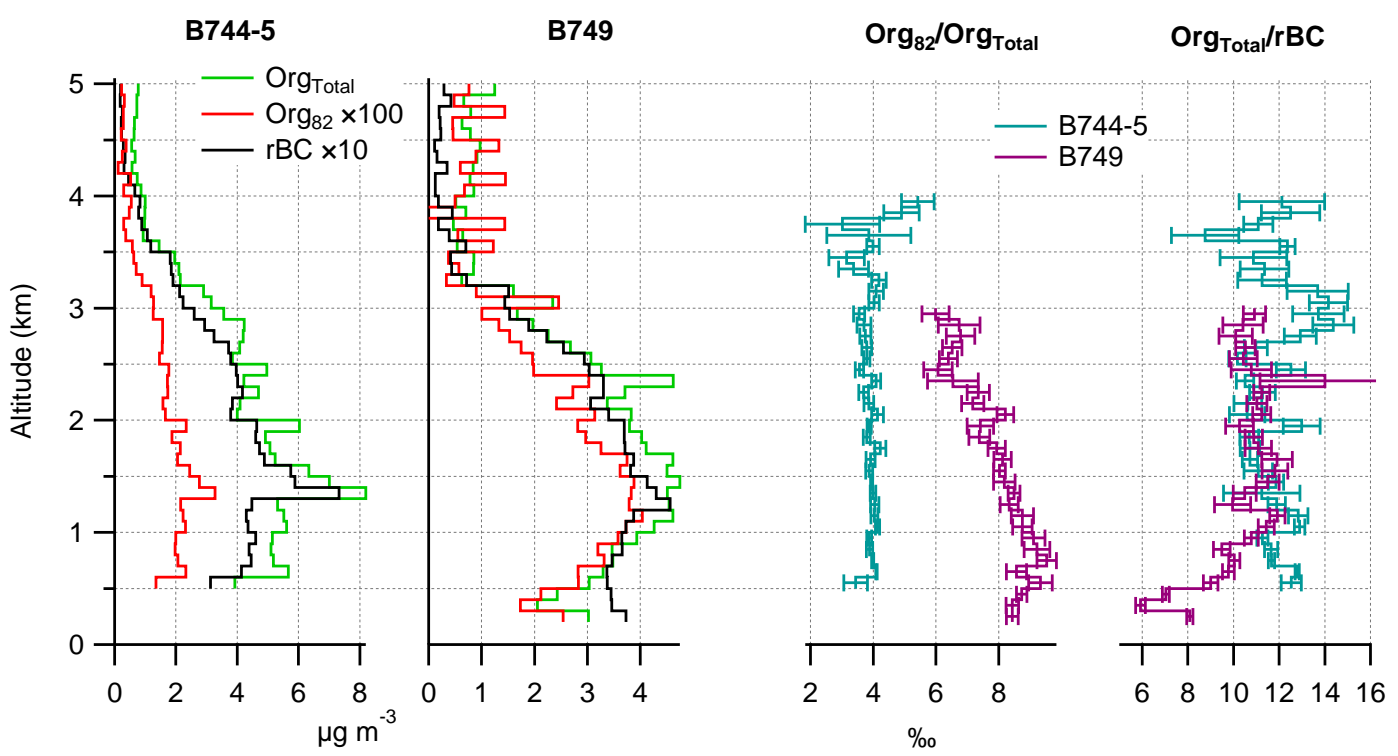

Figure 4. Comparison of mean vertical profiles of B744 and B745 with B749 for the carbonaceous species. The ratios are taken of the average values and the error bars correspond to standard errors. Ratios for higher altitudes showed high degree of variability (and associated errors) and have been omitted for clarity.

roughly constant up to $1.5 \mathrm{~km}$ and showing a marked negative gradient for B744-5, which crosses the value of 25 for B749. While the $M_{30}$ may be due to nitro-aromatics that have been associated with biomass burning (Mohr et al., 2013), the vertical trends presented here do not match with the $\mathrm{rBC}$, so it is not thought to be the case here. The structure in B744-5 is probably due to the ammonium nitrate present during these flights, which will peak in concentration at the top of the boundary layer (Morgan et al., 2010a; Morgan et al., 2009) and suppress the ratio through an inorganic $\mathrm{NO}^{+}$contribution to $M_{30}$.

\section{Discussion}

\subsection{Factors affecting formation}

The presence of the $\operatorname{Org}_{82}$ marker in flights B735, B749 and B750 and its absence in B744 and B745 is consistent with it being due to methylfuran from isoprene SOA via the IEPOX route, being formed in an abundance of isoprene, with the cases where it is present being those with the lower $\mathrm{NO}_{\mathrm{x}}$ concentrations and acidic seed aerosols. It is unfortunate that the wet deposition that took place in $\mathrm{B} 750$ prevented a direct comparison with $\mathrm{B} 749$, which would have allowed the changes in chemistry with time of day to be probed in the same manner as by Robinson et al. (2011).

Unfortunately, based on observations alone, it is not possible to conclusively say which, if any, factor was singularly responsible for the difference in observations. The presence of NO affects the chemical processes through reactions with peroxy radicals, inhibiting the peroxy-peroxy reactions needed to form IEPOX through the ISOPOOH route (Surratt et al., 2010). While model and laboratory systems are frequently referred to as "high $\mathrm{NO}_{\mathrm{x}}$ " and "low $\mathrm{NO}_{\mathrm{x}}$ ", it is difficult to define a discrete cutoff point between the two chemical regimes due to the inherent complexities associated with other aspects of how $\mathrm{NO}_{\mathrm{x}}$ and VOCs interact (Wennberg, 2013). Furthermore, recent work by Jacobs et al. (2014) indicates that it is also possible to form IEPOX from isoprene hydroxynitrates in the "high $\mathrm{NO}_{\mathrm{x}}$ " regime. While all average NO concentrations were below the approximate figure of 100 pptv often given for when NO-peroxy reactions become important (pp 330-331, Faraday Discussions, 2013), without the use of a detailed chemical model (which would be difficult to constrain with the data here), it is difficult to say definitively here whether or not $\mathrm{NO}_{\mathrm{x}}$ concentrations were a significant factor in determining SOA formation. However, it is worth noting that Claeys et al. (2010) found that the isoprene SOA markers in Rondônia were highest during the dry season, corresponding to the highest $\mathrm{NO}_{\mathrm{x}}$ concentrations, so in this context, it would seem unlikely.

The role of aerosol acidity has long been seen as necessary for uptake (Surratt et al., 2007b; Eddingsaas et al., 2010) and this conclusion was supported by observational data from this region presented by Claeys et al. (2010), although recent laboratory results from Nguyen et al. (2014) show that it is possible to form SOA with the $m / z=82$ marker from IEPOX on a neutral ammonium sulfate seed, providing it is aqueous, as opposed to solid. This occurs through ammonium ions $\left(\mathrm{NH}_{4}^{+}\right)$acting to catalyse the uptake in the absence of a proton donor. The conditions during B744 and B745 were drier than B749 and B750, with the respective 


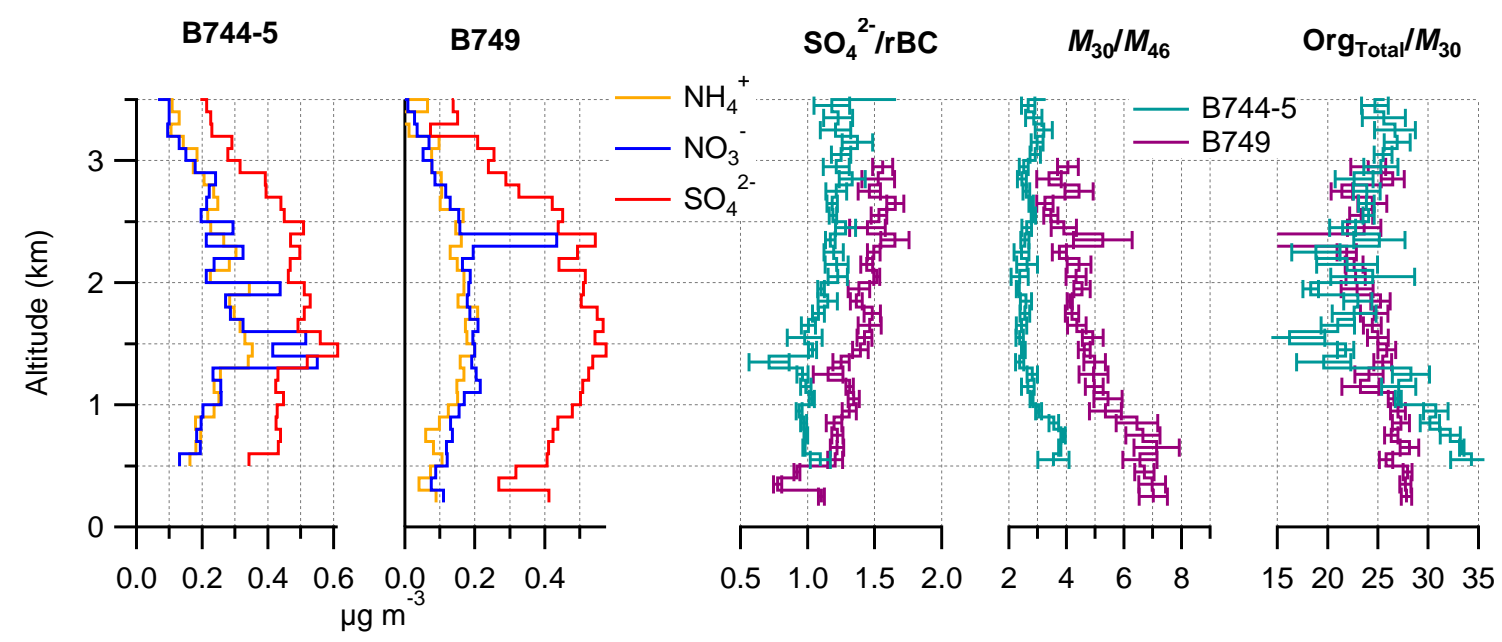

Figure 5. Inorganic vertical profiles for B744-5 and B749. Data above $3.5 \mathrm{~km}$ are omitted for clarity.

measured relative humidities in the boundary layer ranging from approximately 45 to $70 \%$ instead of 60 to $80 \%$. The former humidity range is within the metastable regime for pure ammonium sulfate and according to the work of Song et al. (2013), internally mixed ammonium sulfate and organic particles could effloresce under these conditions. As such, it is possible that the inorganic matter during B749 and B750 existed as a solid or as a non-aqueous organic liquid, which would inhibit the formation through the neutral mechanism of Nguyen et al. (2014). Note that the acidic mechanism explored by Surratt et al. (2007b) was shown to be effective at $30 \% \mathrm{RH}$, so it could be inferred that had the aerosol in B744 and B745 been acidic, formation would have taken place, regardless of humidity. Likewise, it could also be inferred that if B749 and B750 had been less humid, formation could have still taken place, due to the aerosols' acidity.

While there is considerable interest in the literature concerning the role of sulfur and nitrogen in the formation mechanisms (Nguyen et al., 2014; Gomez-Gonzalez et al., 2008; Surratt et al., 2007a), it should be noted that only very limited conclusions can be drawn here. In addition to the $M_{30} / M_{46}$ data possibly indicating some role of organic nitrogen, the sulfate to $\mathrm{rBC}$ ratio shows a positive gradient with altitude within the boundary layer in B749 (albeit a weaker gradient than the equivalent organic ratio). This may point to the measurement being influenced by organosulfates, although the fact that the sulfate ratio continues to increase at a similar rate above $1 \mathrm{~km}$ (unlike the organic ratio) would detract from this argument. Ultimately, while these data give some intriguing results, given the difficulties in discriminating and quantifying organic sulfur and nitrogen species with the AMS (in particular with the C-TOF), it is difficult to see that any strong conclusions can be drawn here. Further investigation will require the use of additional measurement techniques.

\subsection{Boundary layer profile}

B749 provides the best case study when the marker is present and its vertical structure provides many features of interest. The positive gradient through the boundary layer (featuring a doubling of $\mathrm{Org}_{82}$ from 20 to $40 \mathrm{ng} \mathrm{m}^{-3}$ ) could be as a result of the repartitioning of semivolatile material into the aqueous phase due to the reduced temperature and increased particulate water content (Morgan et al., 2010a). This would be consistent with the observations of Fu et al. (2010), who found an increase in isoprene SOA tracers at night-time at an elevated site in China, and the modelling work of Henze and Seinfeld (2006), who predict enhanced partitioning to the particle phase at higher altitudes. To explore the feasibility of this hypothesis, estimates of particulate mass concentrations were made using the PartProp component of the UManSysProp tools (http://umansysprop.seaes.manchester.ac.uk), which predicts equilibrium concentrations according to a Gibbs free energy minimisation, allowing for the organic and water contents to be calculated in tandem (e.g. Topping et al., 2013). The methods of organic vapour pressure and boiling point estimation according to Nannoolal et al. $(2008,2004)$ and non-ideality (including solute-solute interactions) according to AIOMFAC (Zuend et al., 2011; Zuend et al., 2008) were used. A nominal $0.005 \mathrm{nmol} \mathrm{m}^{-3}$ ammonium sulfate seed was assumed (currently, UManSysProp does not allow for inorganic charge imbalance) and particulate organic mass concentrations were compared between conditions typical of the top of the boundary layer $(295 \mathrm{~K}, 80 \% \mathrm{RH})$ and the lowest altitude sampled ( $302 \mathrm{~K}, 60 \% \mathrm{RH})$. While it will never be possible to fully constrain this model with the data available, it should give an indication of how realistic these hypotheses are. Note for the purposes of this model, all gas phase concentrations are given in molecules per $\mathrm{cm}^{3}$.

If one assumes that the dominant component of the particle phase giving rise to the methylfuran marker are the 
3-MeTHF-3,4-diols, it is found that an unrealistically large concentration of $10^{13} \mathrm{~cm}^{-3}$ (corresponding to hundreds of $\mathrm{ppb}$ ) is needed to predict a mass concentration of $45 \mathrm{ng} \mathrm{m}^{-3}$ at the top of the boundary layer, implying that this is not the specific form that is physically present in the particle phase. Given that Lin et al. (2012) reported it as present in ambient particulates (through offline analysis by GC-MS after methanol extraction and trimethylsilation), it is possible that this exists in the particle phase through a chemical uptake process that is reversed during the analytical process. If a dimer of this molecule is considered, it is found that a concentration of $10^{10} \mathrm{~cm}^{-3}$ gives a mass concentration of between 35 and $102 \mathrm{ng} \mathrm{m}^{-3}$ at the top of the boundary layer, depending on the isomer (higher mass concentrations are favoured when both methyl groups are adjacent to the ether group). When these concentrations are compared with the conditions at the bottom of the boundary layer, concentrations between 22 and $55 \mathrm{ng} \mathrm{m}^{-3}$ are predicted, which correspond to a reduction in mass of 37 to $46 \%$. Repeating the calculation for 2-methyltetrol, the concentration at the top of the boundary layer is predicted as $2.08 \mu \mathrm{g} \mathrm{m}^{-3}$, compared to $1.27 \mu \mathrm{g} \mathrm{m}^{-3}$ at the bottom, a reduction of $39 \%$. While this model carries an inherent uncertainty and the actual particulates are likely to be formed of a complex mixture of many species, these estimates show that repartitioning could conceivably be responsible for the observed change in mass with altitude, although it is recognised that if higher order oligomers are the dominant form of SOA mass, these are likely to be less volatile and therefore less likely to exhibit this behaviour. For example, when the calculation is repeated for $10^{10} \mathrm{~cm}^{-3}$ of a 2-methyltetrol dimer, a concentration of $4.22 \mu \mathrm{g} \mathrm{m}^{-3}$ is predicted for both altitudes.

An alternative hypothesis is that the peak at the top of the boundary layer reflects faster production rate of SOA at this altitude. The aerosol concentrations were not sufficient to affect actinic flux within the boundary layer (as evidenced by the aircraft's pyranometer measurements during the profiles), so it is assumed that gas-phase photochemistry was not promoted significantly at the top of the boundary layer. It should be noted that Karl et al. (2007) found evidence of enhanced isoprene photochemistry above the Amazon at cloud level that was attributed to scattered light from cumulous clouds. While this may be possible here, a similar analysis of MVK + MACR relative to isoprene did not show the pronounced enhancement at cloud level noted in that paper. Hypothetically, it is possible that the reduced temperature at altitude may also be affecting the chemical reactions, but this is difficult to test here without detailed modelling that is difficult to constrain.

Instead, it could be that production is promoted by an increased rate of IEPOX uptake. Using the same model conditions described above for the 3-MeTHF-3,4-diol dimer case, but with $10^{10} \mathrm{~cm}^{-3}$ of $\beta$-IEPOX also included, it is predicted that the equilibrium aqueous concentrations of IEPOX will increase by only $3.6 \%$ at the top of the boundary layer (272 to $282 \mathrm{ppm}$ with respect to water). Given this, it would not seem that an increase in concentration due to equilibrium partitioning could be responsible for an increased production rate. Another possible reason for an enhanced production rate could be if the process is kinetically limited by the particulate surface area, which will increase in line with the water content of the particles. However, given the high proportion of organic to inorganic material in the particles (see Table 1), the amount of geometric growth between 60 and $80 \%$ is likely to be small (Gysel et al., 2004); using the HygroProp tool on the 3-MeTHF-3,4-diol dimer case and invoking the density estimation method of Girolami (1994), an increase of only $5.6 \%$ in particle surface area between the two altitudes is predicted, so this again does not seem likely.

Another hypothesis could be that the particles are undergoing phase changes with altitude, which could affect both the partitioning and the production rate of the SOA. As well as the phase effect on inorganic ion chemistry described by Nguyen et al. (2014), the organic fraction is known to potentially exhibit exotic behaviours such as forming amorphous states and separations from the aqueous phase (Virtanen et al., 2010; Song et al., 2013), which may affect how the particles interact with the gas phase. This is a difficult concept to test with the data available, as there are no measurement data on the hygroscopicity of the particles or the exact phase of the organic fraction. However, the humidity during B749 is significantly higher than the B744-5 case and given that the boundary layer is well mixed (providing a means for metastable particles to encounter higher humidities), it would seem reasonable to expect all the particles to be aqueous during B749. Phase is also known to affect the CE of the AMS (Matthew et al., 2008), so it is conceptually possible that rather than altering ambient composition, phase changes are creating an artefact within the AMS. Because the SMPS data are regarded as unreliable during profiles (due to the continuous pressure change affecting flows), a comparison of the AMS-derived volume concentration was compared against an equivalent derived from the SP2 scattering data (calibrated using polystyrene latex spheres). While this method has uncertainties associated with ambiguities in the optical properties of ambient particles, the comparison showed no trend with altitude, implying that there was no change in CE.

A final, somewhat speculative, hypothesis is that the gradient exists because of a loss mechanism at the bottom of the boundary layer, in turn causing a gradient to exist within the well-mixed layer. If one assumes that sulfate is all from out-of-basin sources, this would seem a reasonable explanation because this too exhibits a positive gradient with altitude within the boundary layer during B749. While it is generally assumed that dry deposition is not significant for involatile submicron particles, it is possible that during interactions with the forest canopy (Whitehead et al., 2010), the aerosols are exposed to much higher humidities and undergo growth or even activation, followed by loss by impaction. This would not be inconsistent with the lack of a vertical trend in $\mathrm{rBC}$, as 
these are smaller and less hygroscopic and therefore would be less affected by this process. Given that there are no incanopy data available here, this hypothesis is impossible to test.

\subsection{Free tropospheric profile}

The behaviour above the boundary layer is also of interest. The overall concentrations decrease with altitude as material from the boundary layer is mixed with cleaner and drier free tropospheric air. There is also a shift in composition in terms of $\mathrm{Org}_{82} / \mathrm{Org}_{\text {Total }}$ with altitude. This could be due to mixing with a background of organic matter from a different source (natural or anthropogenic), but if it can be assumed that the material at higher altitudes originally resembled that within the boundary layer, this would offer an insight into the fate of these aerosols.

Figure 6a shows the numerical difference in the normalised mass spectra of organic mass between the boundary layer and the lower free troposphere. The comparison shows a general transition between mass spectra that resembles the evolution from semivolatile (SV) to low volatility (LV) oxygenated organic aerosol (OOA) described by Jimenez et al. (2009), albeit with the presence of the methylfuran marker in the SV-OOA equivalent spectrum. Note that this is not to say that the boundary layer state is necessarily semivolatile, but that it may represent a less chemically aged version of that which is transported higher into the troposphere. This general trend is further reinforced by Fig. 6b, which shows that the $\operatorname{Org}_{44} / \mathrm{Org}_{\text {Total }}$ (often referred to as " $f_{44}$ " elsewhere in the literature) during B749 reaches a minimum at approximately $1 \mathrm{~km}$ (the peak in $\operatorname{Org}_{82} / \mathrm{Org}_{\text {Total }}$ ), with a value of 0.12 , before increasing steadily through to a value of 0.16 at $3 \mathrm{~km}$. Conversely, B744-5 shows a general increase throughout the altitude range.

As it is transported upwards, the organic matter will be subject to oxidation processes (that may include aqueous processing during wet convection), which will add oxygenated functionality (McFiggans et al., 2005; Kroll et al., 2011). As the chemical ageing progresses, the mass spectral profile begins to resemble that of LV-OOA, which is dominated by $\mathrm{CO}_{2}^{+}$from the thermal decomposition of multifunctional species. While this change in profile could be the result of the addition of new, more oxidised SOA on top of the existing material, this is not deemed likely because the

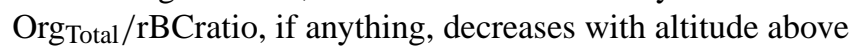
the boundary layer, according to Fig. 4. All this being the case, this has important implications for the usage of methylfuran as an isoprene SOA marker, as it indicates that it is not conserved within the atmosphere and is therefore only useful as a marker in the near field.
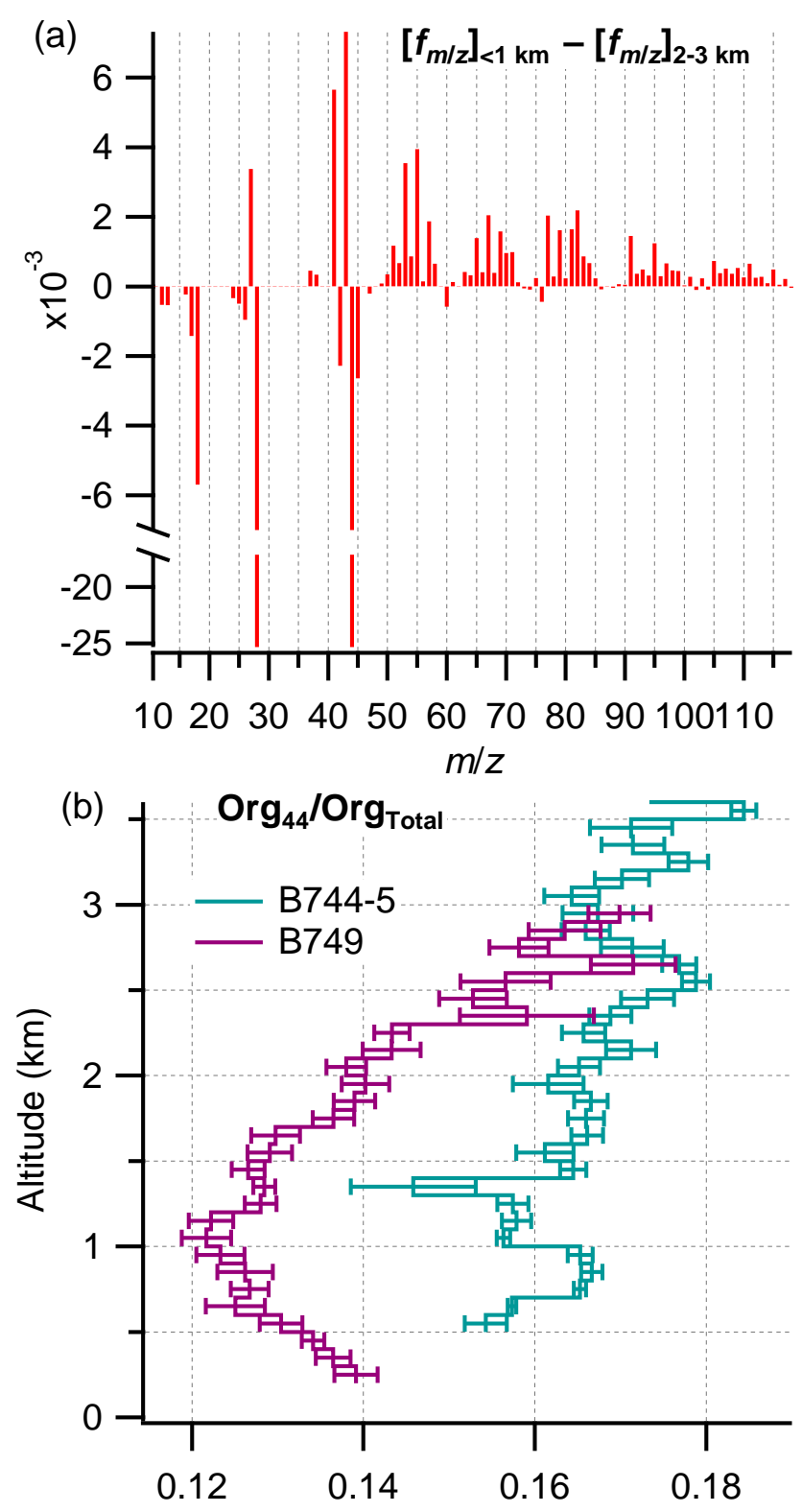

Figure 6. (a) Difference in normalised organic mass spectra between the altitude ranges of less than $1 \mathrm{~km}$ and between 2 and $3 \mathrm{~km}$. (b) Trend in $\mathrm{Org}_{44} / \mathrm{Org}_{\text {Total }}$ with altitude for the two contrasting cases, with standard errors.

\section{Conclusions}

Presented here are AMS observations of organic matter measured above the Amazon rainforest, taken over five flights as part of the SAMBBA campaign on the FAAM BAe-146 research aircraft. Through the investigation of the previously identified marker at $\mathrm{m} / \mathrm{z}=82$ (corresponding to methylfuran), it is suggested that isoprene SOA is being formed within the boundary layer under certain conditions. A comparison between flights where the marker is found with those where it was not indicate behaviour consistent with formation through 
the IEPOX route, with the marker's presence favouring the flights with low $\mathrm{NO}_{\mathrm{x}}$ concentrations, acidic seed particles and higher relative humidity. In addition, data suggest a role of organic nitrogen in the chemistry. It should be noted that the $\mathrm{rBC}$ and $\mathrm{NO}_{\mathrm{x}}$ concentrations were consistently low but exhibited some residual pollution, indicating that conditions do not have to be pristine for this mechanism to take place, in agreement with Claeys et al. (2010).

A specific flight (B749) provided the best case study for this process and an inspection of vertical profiles yielded some interesting behaviour in the organic mass concentrations and the $m / z=82$ marker. Profiles within the boundary layer show that concentrations are greatest at the top of the boundary layer, with thermodynamic calculations showing that semivolatile repartitioning of SOA is a plausible explanation, in line with Henze and Seinfeld (2006). The behaviour of the marker within the free troposphere suggests that through atmospheric processing, the mass spectral profile changes to that of the highly processed organic matter seen in many other environments. While this could be due to mixing with a highly processed free tropospheric background aerosol, it is also consistent with progressive oxidation and functionalisation of the organic matter. If this is the case, it implies that the $m / z=82$ marker is not conserved and therefore may only be suitable as a marker in the near field. More work in the laboratory and comparisons with other observations in the field are needed to investigate these hypotheses further.

\section{Data availability}

Processed data are available at the British Atmospheric Data Centre SAMBBA archive (http://badc.nerc.ac.uk/cgi-bin/ data_browser/data_browser/badc/sambba/data/). Raw data are archived at the University of Manchester and available on request.

Acknowledgements. This work was supported by the UK Natural Environment Research Council (NERC) through the SAMBBA project (grant ref: NE/J010073/1) and a PhD studentship (Eoghan Darbyshire). Airborne data were obtained using the BAe-146-301 Atmospheric Research Aircraft (ARA) flown by Directflight Ltd and managed by the Facility for Airborne Atmospheric Measurements (FAAM), which is a joint entity of NERC and the Met Office. We thank Ben Johnson (Met Office) and Karla M. Longo (National Institute for Space Research - INPE, Brazil) for their roles in coordinating the campaign. Isoprene data from WAS sample analysis were provided by James R. Hopkins (National Centre for Atmospheric Science and University of York). Additional thanks are given to David O. Topping (National Centre for Atmospheric Science and University of Manchester) for helpful discussions and assistance in the use of the UManSysProp tools.

\section{References}

Alfarra, M. R., Prevot, A. S. H., Szidat, S., Sandradewi, J., Weimer, S., Lanz, V. A., Schreiber, D., Mohr, M., and Baltensperger, U.: Identification of the mass spectral signature of organic aerosols from wood burning emissions, Environ. Sci. Technol., 41, 5770-5777, doi:10.1021/Es062289b, 2007.

Allan, J. D., Delia, A. E., Coe, H., Bower, K. N., Alfarra, M. R., Jimenez, J. L., Middlebrook, A. M., Drewnick, F., Onasch, T. B., Canagaratna, M. R., Jayne, J. T., and Worsnop, D. R.: A generalised method for the extraction of chemically resolved mass spectra from aerodyne aerosol mass spectrometer data, J. Aerosol. Sci., 35, 909-922, doi:10.1016/j.jaerosci.2004.02.007, 2004.

Allan, J. D., Alfarra, M. R., Bower, K. N., Coe, H., Jayne, J. T., Worsnop, D. R., Aalto, P. P., Kulmala, M., Hyötyläinen, T., Cavalli, F., and Laaksonen, A.: Size and composition measurements of background aerosol and new particle growth in a Finnish forest during QUEST 2 using an Aerodyne Aerosol Mass Spectrometer, Atmos. Chem. Phys., 6, 315-327, doi:10.5194/acp-6-315-2006, 2006.

Allan, J. D., Williams, P. I., Morgan, W. T., Martin, C. L., Flynn, M. J., Lee, J., Nemitz, E., Phillips, G. J., Gallagher, M. W., and Coe, H.: Contributions from transport, solid fuel burning and cooking to primary organic aerosols in two UK cities, Atmos. Chem. Phys., 10, 647-668, doi:10.5194/acp-10-647-2010, 2010.

Budisulistiorini, S. H., Canagaratna, M. R., Croteau, P. L., Marth, W. J., Baumann, K., Edgerton, E. S., Shaw, S. L., Knipping, E. M., Worsnop, D. R., Jayne, J. T., Gold, A., and Surratt, J. D.: Real-time continuous characterization of secondary organic aerosol derived from isoprene epoxydiols in downtown Atlanta, Georgia, using the aerodyne aerosol chemical speciation monitor, Environ. Sci. Technol., 47, 5686-5694, doi:10.1021/es400023n, 2013.

Canagaratna, M. R., Jayne, J. T., Jimenez, J. L., Allan, J. D., Alfarra, M. R., Zhang, Q., Onasch, T. B., Drewnick, F., Coe, H., Middlebrook, A., Delia, A., Williams, L. R., Trimborn, A. M., Northway, M. J., DeCarlo, P. F., Kolb, C. E., Davidovits, P., and Worsnop, D. R.: Chemical and microphysical characterization of ambient aerosols with the aerodyne aerosol mass spectrometer, Mass Spectrom. Rev., 26, 185-222, doi:10.1002/Mas.20115, 2007.

Capes, G., Johnson, B., McFiggans, G., Williams, P. I., Haywood, J., and Coe, H.: Aging of biomass burning aerosols over West Africa: aircraft measurements of chemical composition, microphysical properties, and emission ratios, J. Geophys. Res.Atmos., 113, D00c15, doi:10.1029/2008jd009845, 2008.

Carlton, A. G., Wiedinmyer, C., and Kroll, J. H.: A review of Secondary Organic Aerosol (SOA) formation from isoprene, Atmos. Chem. Phys., 9, 4987-5005, doi:10.5194/acp-9-4987-2009, 2009.

Chan, M. N., Surratt, J. D., Claeys, M., Edgerton, E. S., Tanner, R. L., Shaw, S. L., Zheng, M., Knipping, E. M., Eddingsaas, N. C., Wennberg, P. O., and Seinfeld, J. H.: Characterization and quantification of isoprene-derived epoxydiols in ambient aerosol in the Southeastern United States, Environ. Sci. Technol., 44, 4590-4596, doi:10.1021/Es100596b, 2010.

Edited by: M. O. Andreae 
Chen, Q., Farmer, D. K., Schneider, J., Zorn, S. R., Heald, C. L., Karl, T. G., Guenther, A., Allan, J. D., Robinson, N., Coe, H., Kimmel, J. R., Pauliquevis, T., Borrmann, S., Poschl, U., Andreae, M. O., Artaxo, P., Jimenez, J. L., and Martin, S. T.: Mass spectral characterization of submicron biogenic organic particles in the Amazon Basin, Geophys. Res. Lett., 36, L20806, doi:10.1029/2009g1039880, 2009.

Chen, Q., Farmer, D. K., Rizzo, L. V., Pauliquevis, T., Kuwata, M., Karl, T. G., Guenther, A., Allan, J. D., Coe, H., Andreae, M. O., Pöschl, U., Jimenez, J. L., Artaxo, P., and Martin, S. T.: Finemode organic mass concentrations and sources in the Amazonian wet season (AMAZE-08), Atmos. Chem. Phys. Discuss., 14, 16151-16186, doi:10.5194/acpd-14-16151-2014, 2014.

Claeys, M., Graham, B., Vas, G., Wang, W., Vermeylen, R., Pashynska, V., Cafmeyer, J., Guyon, P., Andreae, M. O., Artaxo, P., and Maenhaut, W.: Formation of secondary organic aerosols through photooxidation of isoprene, Science, 303, 1173-1176, doi:10.1126/science.1092805, 2004.

Claeys, M., Kourtchev, I., Pashynska, V., Vas, G., Vermeylen, R., Wang, W., Cafmeyer, J., Chi, X., Artaxo, P., Andreae, M. O., and Maenhaut, W.: Polar organic marker compounds in atmospheric aerosols during the LBA-SMOCC 2002 biomass burning experiment in Rondônia, Brazil: sources and source processes, time series, diel variations and size distributions, Atmos. Chem. Phys., 10, 9319-9331, doi:10.5194/acp-10-9319-2010, 2010.

Cross, E. S., Slowik, J. G., Davidovits, P., Allan, J. D., Worsnop, D. R., Jayne, J. T., Lewis, D. K., Canagaratna, M., and Onasch, T. B.: Laboratory and ambient particle density determinations using light scattering in conjunction with aerosol mass spectrometry, Aerosol Sci. Tech., 41, 343-359, doi:10.1080/02786820701199736, 2007.

Cubison, M. J., Ortega, A. M., Hayes, P. L., Farmer, D. K., Day, D., Lechner, M. J., Brune, W. H., Apel, E., Diskin, G. S., Fisher, J. A., Fuelberg, H. E., Hecobian, A., Knapp, D. J., Mikoviny, T., Riemer, D., Sachse, G. W., Sessions, W., Weber, R. J., Weinheimer, A. J., Wisthaler, A., and Jimenez, J. L.: Effects of aging on organic aerosol from open biomass burning smoke in aircraft and laboratory studies, Atmos. Chem. Phys., 11, 12049-12064, doi:10.5194/acp-11-12049-2011, 2011.

Czoschke, N. M., Jang, M., and Kamens, R. M.: Effect of acidic seed on biogenic secondary organic aerosol growth, Atmos. Environ., 37, 4287-4299, 2003.

DeCarlo, P. F., Ulbrich, I. M., Crounse, J., de Foy, B., Dunlea, E. J., Aiken, A. C., Knapp, D., Weinheimer, A. J., Campos, T., Wennberg, P. O., and Jimenez, J. L.: Investigation of the sources and processing of organic aerosol over the Central Mexican Plateau from aircraft measurements during MILAGRO, Atmos. Chem. Phys., 10, 5257-5280, doi:10.5194/acp-10-52572010, 2010.

Drewnick, F., Hings, S. S., DeCarlo, P., Jayne, J. T., Gonin, M., Fuhrer, K., Weimer, S., Jimenez, J. L., Demerjian, K. L., Borrmann, S., and Worsnop, D. R.: A new time-of-flight aerosol mass spectrometer (TOF-AMS)-instrument description and first field deployment, Aerosol Sci. Tech., 39, 637-658, 2005.

Drewnick, F., Hings, S. S., Alfarra, M. R., Prevot, A. S. H., and Borrmann, S.: Aerosol quantification with the Aerodyne Aerosol Mass Spectrometer: detection limits and ionizer background effects, Atmos. Meas. Tech., 2, 33-46, doi:10.5194/amt-2-332009, 2009.
Eddingsaas, N. C., VanderVelde, D. G., and Wennberg, P. O.: Kinetics and products of the acid-catalyzed ring-opening of atmospherically relevant butyl epoxy alcohols, J. Phys. Chem. A, 114, 8106-8113, doi:10.1021/jp103907c, 2010.

Faraday Discussions: General discussion, Faraday Discuss., 165, 317-342, doi:10.1039/C3FD90033A, 2013.

Foltescu, V. L., Selin, E., and Below, M.: Corrections for particle losses and sizing errors during aircraft aerosol sampling using a Rosemount inlet and the Pms Las-X, Atmos. Environ., 29, 449453, 1995.

Fu, P. Q., Kawamura, K., Kanaya, Y., and Wang, Z. F.: Contributions of biogenic volatile organic compounds to the formation of secondary organic aerosols over Mt Tai, Central East China, Atmos. Environ., 44, 4817-4826, doi:10.1016/j.atmosenv.2010.08.040, 2010.

Girolami, G. S.: A simple back of the envelope method for estimating the densities and molecular volumes of liquids and solids, J. Chem. Educ., 71, 962-964, 1994.

Gomez-Gonzalez, Y., Surratt, J. D., Cuyckens, F., Szmigielski, R., Vermeylen, R., Jaoui, M., Lewandowski, M., Offenberg, J. H., Kleindienst, T. E., Edney, E. O., Blockhuys, F., Van Alsenoy, C., Maenhaut, W., and Claeys, M.: Characterization of organosulfates from the photooxidation of isoprene and unsaturated fatty acids in ambient aerosol using liquid chromatography/(-) electrospray ionization mass spectrometry, J. Mass Spectrom., 43, 371-382, doi:10.1002/Jms.1329, 2008.

Guenther, A., Karl, T., Harley, P., Wiedinmyer, C., Palmer, P. I., and Geron, C.: Estimates of global terrestrial isoprene emissions using MEGAN (Model of Emissions of Gases and Aerosols from Nature), Atmos. Chem. Phys., 6, 3181-3210, doi:10.5194/acp-63181-2006, 2006.

Gysel, M., Weingartner, E., Nyeki, S., Paulsen, D., Baltensperger, U., Galambos, I., and Kiss, G.: Hygroscopic properties of water-soluble matter and humic-like organics in atmospheric fine aerosol, Atmos. Chem. Phys., 4, 35-50, doi:10.5194/acp-4-35-2004, 2004.

Hallquist, M., Wenger, J. C., Baltensperger, U., Rudich, Y., Simpson, D., Claeys, M., Dommen, J., Donahue, N. M., George, C., Goldstein, A. H., Hamilton, J. F., Herrmann, H., Hoffmann, T., Iinuma, Y., Jang, M., Jenkin, M. E., Jimenez, J. L., KiendlerScharr, A., Maenhaut, W., McFiggans, G., Mentel, Th. F., Monod, A., Prévôt, A. S. H., Seinfeld, J. H., Surratt, J. D., Szmigielski, R., and Wildt, J.: The formation, properties and impact of secondary organic aerosol: current and emerging issues, Atmos. Chem. Phys., 9, 5155-5236, doi:10.5194/acp-9-51552009, 2009.

Henze, D. K. and Seinfeld, J. H.: Global secondary organic aerosol from isoprene oxidation, Geophys. Res. Lett., 33, L09812, doi:10.1029/2006GL025976, 2006.

Hewitt, C. N., Lee, J. D., MacKenzie, A. R., Barkley, M. P., Carslaw, N., Carver, G. D., Chappell, N. A., Coe, H., Collier, C., Commane, R., Davies, F., Davison, B., DiCarlo, P., Di Marco, C. F., Dorsey, J. R., Edwards, P. M., Evans, M. J., Fowler, D., Furneaux, K. L., Gallagher, M., Guenther, A., Heard, D. E., Helfter, C., Hopkins, J., Ingham, T., Irwin, M., Jones, C., Karunaharan, A., Langford, B., Lewis, A. C., Lim, S. F., MacDonald, S. M., Mahajan, A. S., Malpass, S., McFiggans, G., Mills, G., Misztal, P., Moller, S., Monks, P. S., Nemitz, E., Nicolas-Perea, V., Oetjen, H., Oram, D. E., Palmer, P. I., 
Phillips, G. J., Pike, R., Plane, J. M. C., Pugh, T., Pyle, J. A., Reeves, C. E., Robinson, N. H., Stewart, D., Stone, D., Whalley, L. K., and Yin, X.: Overview: oxidant and particle photochemical processes above a south-east Asian tropical rainforest (the OP3 project): introduction, rationale, location characteristics and tools, Atmos. Chem. Phys., 10, 169-199, doi:10.5194/acp10-169-2010, 2010.

Hopkins, J. R., Jones, C. E., and Lewis, A. C.: A dual channel gas chromatograph for atmospheric analysis of volatile organic compounds including oxygenated and monoterpene compounds, J. Environ. Monitor., 13, 2268-2276, doi:10.1039/C1EM10050E, 2011.

Jacobs, M. I., Burke, W. J., and Elrod, M. J.: Kinetics of the reactions of isoprene-derived hydroxynitrates: gas phase epoxide formation and solution phase hydrolysis, Atmos. Chem. Phys., 14, 8933-8946, doi:10.5194/acp-14-8933-2014, 2014.

Jimenez, J. L., Canagaratna, M. R., Donahue, N. M., Prevot, A. S. H., Zhang, Q., Kroll, J. H., DeCarlo, P. F., Allan, J. D., Coe, H., Ng, N. L., Aiken, A. C., Docherty, K. S., Ulbrich, I. M., Grieshop, A. P., Robinson, A. L., Duplissy, J., Smith, J. D., Wilson, K. R., Lanz, V. A., Hueglin, C., Sun, Y. L., Tian, J., Laaksonen, A., Raatikainen, T., Rautiainen, J., Vaattovaara, P., Ehn, M., Kulmala, M., Tomlinson, J. M., Collins, D. R., Cubison, M. J., E, Dunlea, J., Huffman, J. A., Onasch, T. B., Alfarra, M. R., Williams, P. I., Bower, K., Kondo, Y., Schneider, J., Drewnick, F., Borrmann, S., Weimer, S., Demerjian, K., Salcedo, D., Cottrell, L., Griffin, R., Takami, A., Miyoshi, T., Hatakeyama, S., Shimono, A., Sun, J. Y., Zhang, Y. M., Dzepina, K., Kimmel, J. R., Sueper, D., Jayne, J. T., Herndon, S. C., Trimborn, A. M., Williams, L. R., Wood, E. C., Middlebrook, A. M., Kolb, C. E., Baltensperger, U., and Worsnop, D. R.: Evolution of organic aerosols in the atmosphere, Science, 326, 1525-1529, doi:10.1126/science.1180353, 2009.

Karl, T., Guenther, A., Yokelson, R. J., Greenberg, J., Potosnak, M., Blake, D. R., and Artaxo, P.: The tropical forest and fire emissions experiment: Emission, chemistry, and transport of biogenic volatile organic compounds in the lower atmosphere over Amazonia, J. Geophys. Res.-Atmos., 112, D18302, doi:10.1029/2007jd008539, 2007.

Kiendler-Scharr, A., Andres, S., Bachner, M., Behnke, K., Broch, S., Hofzumahaus, A., Holland, F., Kleist, E., Mentel, T. F., Rubach, F., Springer, M., Steitz, B., Tillmann, R., Wahner, A., Schnitzler, J. P., and Wildt, J.: Isoprene in poplar emissions: effects on new particle formation and $\mathrm{OH}$ concentrations, Atmos. Chem. Phys., 12, 1021-1030, doi:10.5194/acp-12-10212012, 2012.

Kroll, J., Ng, N., Murphy, S., Flagan, R., and Seinfeld, J.: Secondary organic aerosol formation from isoprene photooxidation, Environ. Sci. Technol., 40, 1869-1877, doi10.1021/es0524301, 2006.

Kroll, J. H., Donahue, N. M., Jimenez, J. L., Kessler, S. H., Canagaratna, M. R., Wilson, K. R., Altieri, K. E., Mazzoleni, L. R., Wozniak, A. S., Bluhm, H., Mysak, E. R., Smith, J. D., Kolb, C. E., and Worsnop, D. R.: Carbon oxidation state as a metric for describing the chemistry of atmospheric organic aerosol, Nature Chem., 3, 133-139, doi:10.1038/nchem.948, 2011.

Laborde, M., Mertes, P., Zieger, P., Dommen, J., Baltensperger, U., and Gysel, M.: Sensitivity of the Single Particle Soot Photometer to different black carbon types, Atmos. Meas. Tech., 5, 10311043, doi:10.5194/amt-5-1031-2012, 2012a.

Laborde, M., Schnaiter, M., Linke, C., Saathoff, H., Naumann, K.H., Möhler, O., Berlenz, S., Wagner, U., Taylor, J. W., Liu, D., Flynn, M., Allan, J. D., Coe, H., Heimerl, K., Dahlkötter, F., Weinzierl, B., Wollny, A. G., Zanatta, M., Cozic, J., Laj, P., Hitzenberger, R., Schwarz, J. P., and Gysel, M.: Single Particle Soot Photometer intercomparison at the AIDA chamber, Atmos. Meas. Tech., 5, 3077-3097, doi:10.5194/amt-5-3077-2012, 2012b.

Lin, Y. H., Zhang, Z. F., Docherty, K. S., Zhang, H. F., Budisulistiorini, S. H., Rubitschun, C. L., Shaw, S. L., Knipping, E. M., Edgerton, E. S., Kleindienst, T. E., Gold, A., and Surratt, J. D.: Isoprene epoxydiols as precursors to secondary organic aerosol formation: acid-catalyzed reactive uptake studies with authentic compounds, Environ. Sci. Technol., 46, 250-258, doi:10.1021/Es202554c, 2012.

Matthew, B. M., Middlebrook, A. M., and Onasch, T. B.: Collection efficiencies in an Aerodyne Aerosol Mass Spectrometer as a function of particle phase for laboratory generated aerosols, Aerosol Sci. Tech., 42, 884-898, 2008.

McFiggans, G., Alfarra, M. R., Allan, J., Bower, K., Coe, H., Cubison, M., Topping, D., Williams, P., Decesari, S., Facchini, C., and Fuzzi, S.: Simplification of the representation of the organic component of atmospheric particulates, Faraday Discuss., 130, 341-362, doi:10.1039/B419435g, 2005.

McMeeking, G. R., Hamburger, T., Liu, D., Flynn, M., Morgan, W. T., Northway, M., Highwood, E. J., Krejci, R., Allan, J. D., Minikin, A., and Coe, H.: Black carbon measurements in the boundary layer over western and northern Europe, Atmos. Chem. Phys., 10, 9393-9414, doi:10.5194/acp-10-93932010, 2010.

Middlebrook, A. M., Bahreini, R., Jimenez, J. L., and Canagaratna, M. R.: Evaluation of Composition-Dependent Collection Efficiencies for the Aerodyne Aerosol Mass Spectrometer using Field Data, Aerosol Sci. Tech., 46, 258-271, doi:10.1080/02786826.2011.620041, 2012.

Mohr, C., Lopez-Hilfiker, F. D., Zotter, P., Prevot, A. S. H., Xu, L., Ng, N. L., Herndon, S. C., Williams, L. R., Franklin, J. P., Zahniser, M. S., Worsnop, D. R., Knighton, W. B., Aiken, A. C., Gorkowski, K. J., Dubey, M. K., Allan, J. D., and Thornton, J. A.: Contribution of Nitrated Phenols to Wood Burning Brown Carbon Light Absorption in Detling, United Kingdom during Winter Time, Environ. Sci. Technol., 47, 6316-6324, doi:10.1021/Es400683v, 2013.

Morgan, W. T., Allan, J. D., Bower, K. N., Capes, G., Crosier, J., Williams, P. I., and Coe, H.: Vertical distribution of sub-micron aerosol chemical composition from North-Western Europe and the North-East Atlantic, Atmos. Chem. Phys., 9, 5389-5401, doi:10.5194/acp-9-5389-2009, 2009.

Morgan, W. T., Allan, J. D., Bower, K. N., Esselborn, M., Harris, B., Henzing, J. S., Highwood, E. J., Kiendler-Scharr, A., McMeeking, G. R., Mensah, A. A., Northway, M. J., Osborne, S., Williams, P. I., Krejci, R., and Coe, H.: Enhancement of the aerosol direct radiative effect by semi-volatile aerosol components: airborne measurements in North-Western Europe, Atmos. Chem. Phys., 10, 8151-8171, doi:10.5194/acp-10-8151-2010, 2010a. 
Morgan, W. T., Allan, J. D., Bower, K. N., Highwood, E. J., Liu, D., McMeeking, G. R., Northway, M. J., Williams, P. I., Krejci, R., and Coe, H.: Airborne measurements of the spatial distribution of aerosol chemical composition across Europe and evolution of the organic fraction, Atmos. Chem. Phys., 10, 4065-4083, doi:10.5194/acp-10-4065-2010, 2010b.

Murphy, J. G., Oram, D. E., and Reeves, C. E.: Measurements of volatile organic compounds over West Africa, Atmos. Chem. Phys., 10, 5281-5294, doi:10.5194/acp-10-5281-2010, 2010.

Nannoolal, Y., Rarey, J., Ramjugernath, D., and Cordes, W.: Estimation of pure component properties - Part 1. Estimation of the normal boiling point of non-electrolyte organic compounds via group contributions and group interactions, Fluid Phase Equilibr., 226, 45-63, doi:10.1016/j.fluid.2004.09.001, 2004.

Nannoolal, Y., Rarey, J., and Ramjugernath, D.: Estimation of pure component properties - Part 3. Estimation of the vapor pressure of non-electrolyte organic compounds via group contributions and group interactions, Fluid Phase Equilibr., 269, $117-$ 133, doi:10.1016/j.fluid.2008.04.020, 2008.

Ng, N. L., Herndon, S. C., Trimborn, A., Canagaratna, M. R., Croteau, P. L., Onasch, T. B., Sueper, D., Worsnop, D. R., Zhang, Q., Sun, Y. L., and Jayne, J. T.: An Aerosol Chemical Speciation Monitor (ACSM) for routine monitoring of the composition and mass concentrations of ambient aerosol, Aerosol Sci. Tech., 45, 780-794, doi:10.1080/02786826.2011.560211, 2011.

Nguyen, T. B., Coggon, M. M., Bates, K. H., Zhang, X., Schwantes, R. H., Schilling, K. A., Loza, C. L., Flagan, R. C., Wennberg, P. O., and Seinfeld, J. H.: Organic aerosol formation from the reactive uptake of isoprene epoxydiols (IEPOX) onto non-acidified inorganic seeds, Atmos. Chem. Phys., 14, 34973510, doi:10.5194/acp-14-3497-2014, 2014.

Paulot, F., Crounse, J. D., Kjaergaard, H. G., Kürten, A., St. Clair, J. M., Seinfeld, J. H., and Wennberg, P. O.: Unexpected epoxide formation in the gas-phase photooxidation of isoprene, Science, 325, 730-733, doi:10.1126/science.1172910, 2009.

Petzold, A., Ogren, J. A., Fiebig, M., Laj, P., Li, S.-M., Baltensperger, U., Holzer-Popp, T., Kinne, S., Pappalardo, G., Sugimoto, N., Wehrli, C., Wiedensohler, A., and Zhang, X.-Y.: Recommendations for reporting "black carbon" measurements, Atmos. Chem. Phys., 13, 8365-8379, doi:10.5194/acp-13-83652013, 2013.

Pike, R. C., Lee, J. D., Young, P. J., Carver, G. D., Yang, X., Warwick, N., Moller, S., Misztal, P., Langford, B., Stewart, D., Reeves, C. E., Hewitt, C. N., and Pyle, J. A.: $\mathrm{NO}_{\mathrm{x}}$ and $\mathrm{O}_{3}$ above a tropical rainforest: an analysis with a global and box model, Atmos. Chem. Phys., 10, 10607-10620, doi:10.5194/acp10-10607-2010, 2010.

Pye, H. O. T., Pinder, R. W., Piletic, I. R., Xie, Y., Capps, S. L., Lin, Y.-H., Surratt, J. D., Zhang, Z., Gold, A., Luecken, D. J., Hutzell, W. T., Jaoui, M., Offenberg, J. H., Kleindienst, T. E., Lewandowski, M., and Edney, E. O.: Epoxide pathways improve model predictions of isoprene markers and reveal key role of acidity in aerosol formation, Environ. Sci. Technol., 47, 1105611064, doi:10.1021/es402106h, 2013.

Robinson, N. H., Hamilton, J. F., Allan, J. D., Langford, B., Oram, D. E., Chen, Q., Docherty, K., Farmer, D. K., Jimenez, J. L., Ward, M. W., Hewitt, C. N., Barley, M. H., Jenkin, M. E., Rickard, A. R., Martin, S. T., McFiggans, G., and
Coe, H.: Evidence for a significant proportion of Secondary Organic Aerosol from isoprene above a maritime tropical forest, Atmos. Chem. Phys., 11, 1039-1050, doi:10.5194/acp-11-10392011, 2011.

Robinson, N. H., Allan, J. D., Trembath, J. A., Rosenberg, P. D., Allen, G., and Coe, H.: The lofting of Western Pacific regional aerosol by island thermodynamics as observed around Borneo, Atmos. Chem. Phys., 12, 5963-5983, doi:10.5194/acp-12-59632012, 2012.

Slowik, J. G., Brook, J., Chang, R. Y.-W., Evans, G. J., Hayden, K., Jeong, C.-H., Li, S.-M., Liggio, J., Liu, P. S. K., McGuire, M., Mihele, C., Sjostedt, S., Vlasenko, A., and Abbatt, J. P. D.: Photochemical processing of organic aerosol at nearby continental sites: contrast between urban plumes and regional aerosol, Atmos. Chem. Phys., 11, 2991-3006, doi:10.5194/acp-11-29912011, 2011.

Song, M., Marcolli, C., Krieger, U. K., Lienhard, D. M., and Peter, T.: Morphologies of mixed organic/inorganic/aqueous aerosol droplets, Faraday Discuss., 165, 289-316, doi:10.1039/C3FD00049D, 2013.

Surratt, J. D., Kroll, J. H., Kleindienst, T. E., Edney, E. O., Claeys, M., Sorooshian, A., Ng, N. L., Offenberg, J. H., Lewandowski, M., Jaoui, M., Flagan, R. C., and Seinfeld, J. H.: Evidence for organosulfates in secondary organic aerosol, Environ. Sci. Technol., 41, 517-527, doi:10.1021/Es062081q, 2007a

Surratt, J. D., Lewandowski, M., Offenberg, J. H., Jaoui, M., Kleindienst, T. E., Edney, E. O., and Seinfeld, J. H.: Effect of acidity on secondary organic aerosol formation from isoprene, Environ. Sci. Technol., 41, 5363-5369, doi:10.1021/Es0704176, $2007 \mathrm{~b}$.

Surratt, J. D., Chan, A. W. H., Eddingsaas, N. C., Chan, M. N., Loza, C. L., Kwan, A. J., Hersey, S. P., Flagan, R. C., Wennberg, P. O., and Seinfeld, J. H.: Reactive intermediates revealed in secondary organic aerosol formation from isoprene, P. Natl. Acad. Sci. USA, 107, 6640-6645, doi:10.1073/pnas.0911114107, 2010.

Topping, D., Connolly, P., and McFiggans, G.: Cloud droplet number enhanced by co-condensation of organic vapours, Nat. Geosci., 6, 443-446, doi:10.1038/ngeo1809, 2013.

Trembath, J., Bart, M., and Brooke, J.: Efficiencies of modified rosemount housings for sampling aerosol on a fast atmospheric research aircraft, http://www.faam.ac.uk/index.php/component/ docman/doc_download/1673-inlet-efficiency (last access: 16 May 2014), FAAM Technical Note 01, FAAM, University of Cranfield, UK, 2012.

Ulbrich, I. M., Canagaratna, M. R., Zhang, Q., Worsnop, D. R., and Jimenez, J. L.: Interpretation of organic components from Positive Matrix Factorization of aerosol mass spectrometric data, Atmos. Chem. Phys., 9, 2891-2918, doi:10.5194/acp-9-2891-2009, 2009.

Virtanen, A., Joutsensaari, J., Koop, T., Kannosto, J., Yli-Pirila, P., Leskinen, J., Makela, J. M., Holopainen, J. K., Poschl, U., Kulmala, M., Worsnop, D. R., and Laaksonen, A.: An amorphous solid state of biogenic secondary organic aerosol particles, Nature, 467, 824-827, doi:10.1038/Nature09455, 2010.

Wennberg, P.: Let's abandon the "high $\mathrm{NO}_{\mathrm{x}}$ " and "low $\mathrm{NO}_{\mathrm{x}}$ " terminology, IGAC news, 50, 2-3, 2013.

Whitehead, J. D., Gallagher, M. W., Dorsey, J. R., Robinson, N., Gabey, A. M., Coe, H., McFiggans, G., Flynn, M. J., Ryder, J., Nemitz, E., and Davies, F.: Aerosol fluxes and dynamics within 
and above a tropical rainforest in South-East Asia, Atmos. Chem. Phys., 10, 9369-9382, doi:10.5194/acp-10-9369-2010, 2010.

Zuend, A., Marcolli, C., Luo, B. P., and Peter, T.: A thermodynamic model of mixed organic-inorganic aerosols to predict activity coefficients, Atmos. Chem. Phys., 8, 4559-4593, doi:10.5194/acp8-4559-2008, 2008.
Zuend, A., Marcolli, C., Booth, A. M., Lienhard, D. M., Soonsin, V., Krieger, U. K., Topping, D. O., McFiggans, G., Peter, T., and Seinfeld, J. H.: New and extended parameterization of the thermodynamic model AIOMFAC: calculation of activity coefficients for organic-inorganic mixtures containing carboxyl, hydroxyl, carbonyl, ether, ester, alkenyl, alkyl, and aromatic functional groups, Atmos. Chem. Phys., 11, 9155-9206, doi:10.5194/acp11-9155-2011, 2011. 